Synt heses of wasabi phyt oal exi n ( net hyl

1- met hoxyi ndol e- 3 - car boxyl at e) and i t s 5-i odo der i vat i ve, and thei $r$ nucl eophi I i $c$ subst i t ut $i$ on react $i$ ons

\begin{tabular}{|l|l|}
\hline 著者 & $\begin{array}{l}\text { Somei Nasanor i , Tani not o Asuka, Or i t a H t omi , } \\
\text { Yanada Fumi o, Ont a Toshi har u }\end{array}$ \\
\hline $\begin{array}{l}\text { j our nal or } \\
\text { publ i cat i on t i t l e }\end{array}$ & Het er ocycl es \\
\hline vol une & 54 \\
\hline nunber & 1 \\
\hline page r ange & $425-432$ \\
\hline year & 2001- 01-01 \\
\hline URL & ht t p: //hdl . handl e. net /2297/4363 \\
\hline
\end{tabular}




\title{
SYNTHESES OF WASABI PHYTOALEXIN (METHYL 1-METHOXYIN- DOLE-3-CARBOXYLATE) AND ITS 5-IODO DERIVATIVE, AND THEIR NUCLEOPHILIC SUBSTITUTION REACTIONS 1
}

\author{
Masanori Somei, ${ }^{*}$ Asuka Tanimoto, Hitomi Orita, Fumio Yamada, and \\ Toshiharu Ohta \\ Faculty of Pharmaceutical Sciences, Kanazawa University, \\ 13-1 Takara-machi, Kanazawa 920-0934, Japan
}

\begin{abstract}
A simple synthetic method for methyl 1-methoxyindole-3-carboxylate, a phytoalexin isolated from Wasabia joponica, syn. Eutrema wasabi, and its 5-iodo derivative is reported. They underwent nucleophilic substitution reactions selectively at the 2 -position.
\end{abstract}

Soledade and co-workers ${ }^{2}$ isolated methyl 1-methoxyindole-3-carboxylate ${ }^{3}$ (1a) from Wasabi (Wasabia japonica, syn. Eutrema wasabi as a phytoalexin (Scheme 1). They determined its structure by direct comparison with the authentic sample, obtained in $6 \%$ overall yield from indoline (2) in six steps without characterizing any intermediates at all. In the synthesis, our synthetic method for 1-methoxyindole (3) from 2 with $\mathrm{NaWO}_{4} \cdot 2 \mathrm{H}_{2} \mathrm{O}$ and $30 \% \mathrm{H}_{2} \mathrm{O}_{2}{ }^{4}$ was applied as a key step. ${ }^{2}$ The compound (1a) itself had already been synthesized by Acheson and co-workers ${ }^{3}$ in ten steps from $o$-nitroaniline in poor overall yield.

We have disclosed that 1-methoxyindoles having electron withdrawing group such as formyl (4a) $)^{3,5}$ and acetyl ${ }^{6}(\mathbf{4 b})$ at the 3 -position readily undergo nucleophilic substitution reactions ${ }^{7}$ regioselectively at the 2-position. Therefore, we have been much interested in $\mathbf{1 a}$ and $\mathbf{4 a}, \mathbf{b}$ for determining whether their reactivities are correlated with antifungal activities or not. In this report, we wish to describe an effective and simple syntheses of 1a, 1-methoxyindole-3-carboxylic acid (5), and 5-iodo derivative (6), as well as their nucleophilic substitution reactions comparing with those of $\mathbf{4 a}, \mathbf{b}$.

First, we have succeeded in the synthesis of $1 \mathrm{a}$ from 2 in only five steps with $51 \%$ overall yield. Thus, according to our previous report, 4 1-methoxyindole-3-carbaldehyde (4a), a phytoalexin found by Takasugi $8 \mathrm{a}$ and co-workers from plant family Cruciferae, was prepared in three steps with $54 \%$ overall yield from 2. Further oxidation of $4 \mathbf{a}$ with $\mathrm{NaClO}_{2}{ }^{9}$ was successful to give $95 \%$ yield of 5 as stable colorless prisms melting at $173-174^{\circ} \mathrm{C}$. These physical data are different from the reported off-white powder melting at $164-165^{\circ} \mathrm{C}\left(\right.$ decomp) by Acheson and co-workers. ${ }^{3}$ Subsequent methylation of 5 with $\mathrm{CH}_{2} \mathrm{~N}_{2}$ provided a quantitative yield of $1 \mathrm{a}$ as stable colorless prisms, $\mathrm{mp} 45-46^{\circ} \mathrm{C}$. These data are not consistent with the reported pink prisms, ${ }^{3} \mathrm{mp} 39-40^{\circ} \mathrm{C}$, either. These facts show that pure $1 \mathrm{a}$ and 5 are now produced for the first time.

We next examined iodination of $1 \mathrm{a}$ with $\mathrm{KI}$ and $\mathrm{NaIO}_{4}{ }^{10}$ in $\mathrm{TFA}-\mathrm{H}_{2} \mathrm{O}$. It is interesting to note that the desired methyl 5-iodo-1-methoxyindole-3-carboxylate (6) was produced predominantly in 69\% yield, 


\section{Scheme 1}

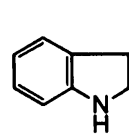

2
1) $\mathrm{Na}_{2} \mathrm{WO}_{4} \cdot 2 \mathrm{H}_{2} \mathrm{O}, 30 \% \mathrm{H}_{2} \mathrm{O}_{2}$

2) $\mathrm{Me}_{2} \mathrm{SO}_{4}, \mathrm{~K}_{2} \mathrm{CO}_{3}$

$61 \%$

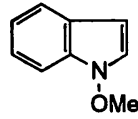

3
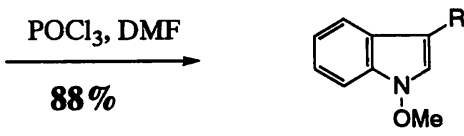

4 a) $\begin{aligned} & \mathrm{R}=\mathrm{CHO} \\ & \mathrm{R}=\mathrm{COM}\end{aligned}$ $\mathrm{NaClO}_{2} \downarrow \mathbf{9 5 \%}$

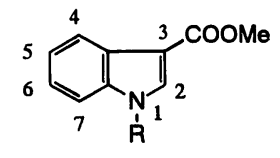

1 a) $\mathrm{R}=\mathrm{OMe}$

b) $\mathbf{R}=\mathbf{H}$

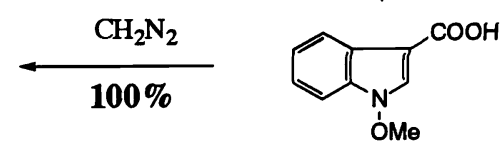

5

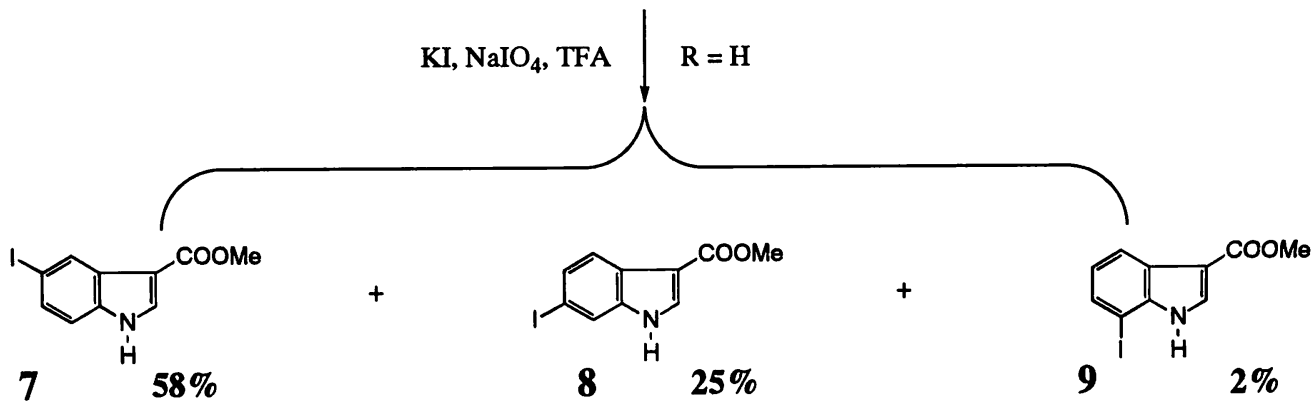

while under similar reaction conditions the iodination of methyl indole-3-carboxylate (1b) gave 5-iodo(7), 6-iodo- (8), and 7-iodo compound (9) in 58, 25, and $2 \%$ yields, respectively. The results suggest that the introduction of 1-methoxy group would be an useful means for realizing regioselective electrophilic substitution reactions at the 5-position.

The structure of 6 was proved by comparing its ${ }^{1} \mathrm{H}-\mathrm{NMR}$ spectrum with that of $1 \mathrm{a}$. The multiplet C(4)proton of 1a, readily discernible in the spectrum because of resonating at the lowest field among other proton signals due to the anisotropy effect of the methoxycarbonyl moiety, changed to meta-coupled doublet $(J=2 \mathrm{~Hz})$ in the spectrum of 6 , proving it to be 5-substituted compound. Similar results were observed in the case of 7. In the spectrum of 8, the $\mathrm{C}(4)$-proton is an ortho- and para-coupled double doublets $(J=8$ and $0.5 \mathrm{~Hz})$ showing it to be 6-substituted compound. The compound $(9)$ is shown to be 7 -substituted indole because the $\mathrm{C}(4)$-proton appears as an ortho- and meta-coupled double doublets $(\mathrm{J}=$ 8 and $1 \mathrm{~Hz}$ ).

With 1a and 6 in hand, their nucleophilic substitution reactions were examined. The reaction of 1a with excess $15 \%$ aqueous NaSMe produced methyl 2-methylthioindole-3-carboxylate (10) and 5 , and the results are summarized in Table 1. Throughout these experiments, formation of 2-methylthioindole-3-carboxylic acid (11) was not observed. These facts indicate that once 5 is formed, it does not undergo nucleophilic substitution reaction, in addition hydrolysis of ester group of $\mathbf{1 0}$ to $\mathbf{1 1}$ does not occur because 
of the resonance-stabilization by the lone pair electrons on the methylthio sulfur atom. Eventually, under the reaction conditions in the Entry 4, 10 was obtained in $70 \%$ yield. In contrast, under such milder conditions as refluxing in $\mathrm{MeOH}$ for $2 \mathrm{~h}, \mathbf{4 a}$ and $\mathbf{4 b}$ reacted with $15 \%$ aqueous $\mathrm{NaSMe}$ to give brassicanal $\mathrm{A}^{8 \mathrm{a}, \mathrm{b}}(\mathbf{1 2})$ and 2-methylthio-3-acetylindole $6(13)$ in quantitative yields, respectively.

\section{Table 1}

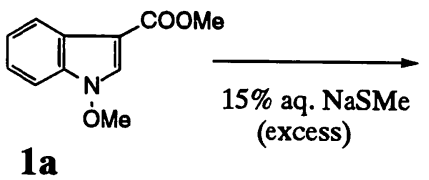

$1 a$

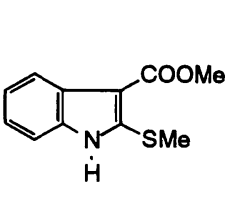

10

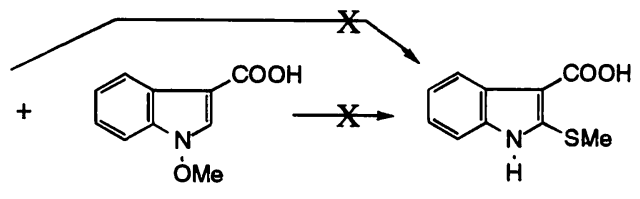

5

11

\begin{tabular}{cccccc}
\hline \multirow{2}{*}{ Entry } & Solvent & \multicolumn{2}{c}{ Reaction Conditions } & \multicolumn{2}{c}{ Yield (\%) of } \\
& & Temp. $\left({ }^{\circ} \mathrm{C}\right)$ & Time $(\mathrm{h})$ & $\mathbf{1 0}$ & $\mathbf{5}$ \\
\hline 1 & $\mathrm{MeOH}$ & reflux & 2 & 0 & 47 \\
2 & $\mathrm{MeOH}$ & $\mathrm{rt}$ & 48 & 5 & 94 \\
3 & $\mathrm{DMF}$ & reflux & 3 & 22 & 72 \\
4 & $\mathrm{DMF}$ & 60 & 6 & 70 & 29 \\
\hline
\end{tabular}

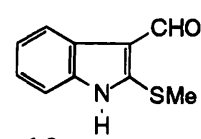

12

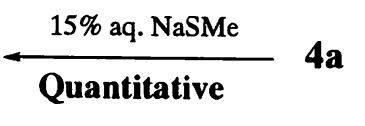

Quantitative
$4 \mathbf{b}$

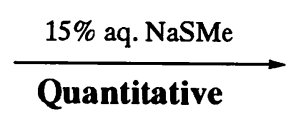

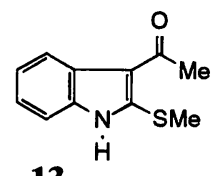

13

The reaction of $1 \mathrm{a}$ with sodium indolyl in DMF at room temperature afforded methyl 2-(indol-1-yl)indole-3-carboxylate (14) in $77 \%$ yield, while the similar reaction of 4 a provided 2-(indol-1-yl)indole-3carbaldehyde $^{5}$ (15) in $95 \%$ yield (Scheme 2). Sodium imidazolyl reacted with 1a in DMF at $60^{\circ} \mathrm{C}$ to afford methyl 2-(imidazol-1-yl)indole-3-carboxylate (16), methyl indole-3-carboxylate (17) and unreacted 1a in 28,11 , and $36 \%$ yields, respectively. The corresponding reaction of $\mathbf{4 a}$ with sodium imidazolyl provided 2-(imidazol-1-yl)indole-3-carbaldehyde 5 (18) in $81 \%$ yield even at room temperature.

Remarkable enhancement in the reactivity of the nucleophilic substitution was observed by the introduction of halogen onto the indole ring. Thus, methyl 2-(imidazol-1-yl)-5-iodoindole-3-carboxylate (19) was produced in $72 \%$ yield in the reaction of 6 with sodium imidazolyl in DMF at $60^{\circ} \mathrm{C}$, in contrast to the yield of $28 \%$ in the case of $\mathbf{1 6}$ as described above. In the reaction of 6 with the most reactive sodium indolyl, the yield (77\%) of methyl 2-(indol-1-yl)-5-iodoindole-3-carboxylate (20) was almost the same as that of the corresponding reaction of $\mathbf{1 a}$.

As reported in the previous papers, ${ }^{6,11}$ sodium dimethylmalonate reacted smoothly with $\mathbf{4 a}$ and $\mathbf{4 b}$ giving 21a, b and 22, respectively. On the other hand, the reaction of 1a with sodium dimethylmalonate did not form the desired 23 under various examined conditions, while similar $\mathrm{KO} t$-Bu promoted reaction of 6 provided 24 in $25 \%$ yield. 


\section{Scheme 2}

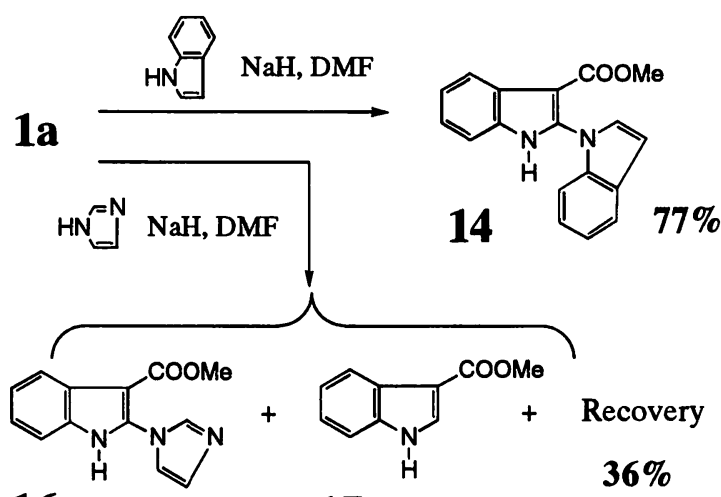

16 29\%

$1711 \%$
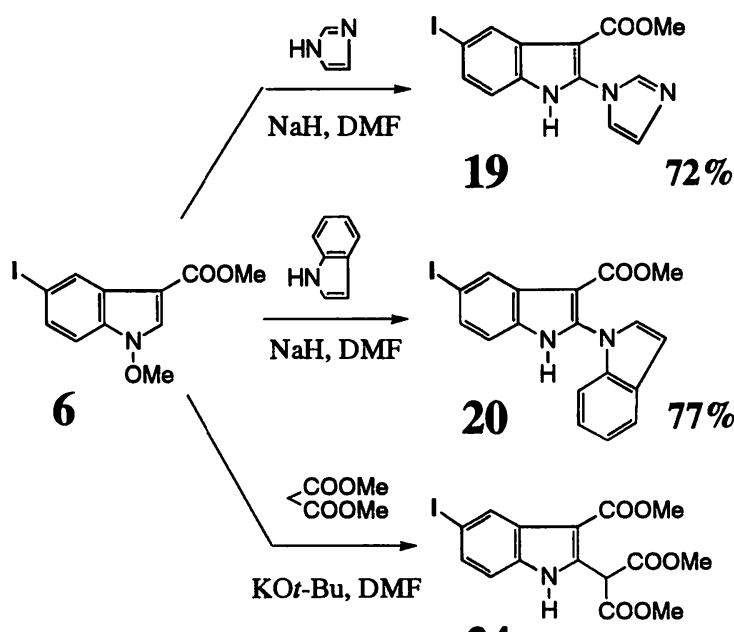

24

$25 \%$

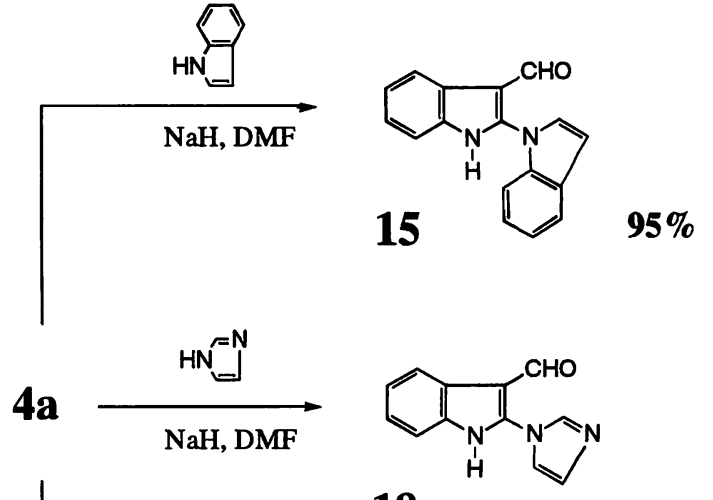

18

$81 \%$<smiles>[R]C(C(C)=O)c1[nH]c2ccccc2c1C=O</smiles>

21 a) $\mathrm{R}=$ COOMe $53 \%$

b) $\mathrm{R}=\mathrm{H}$

$7 \%$

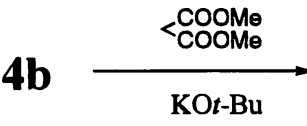<smiles>COC(=O)C(C(C)=O)c1[nH]c2ccccc2c1C(C)=O</smiles>

22

$51 \%$

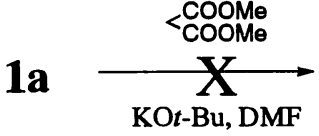

23

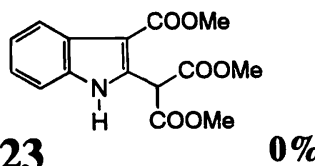

In conclusion, we succeeded in establishing a simple five steps synthetic method for 1a from 2 . Utilizing the route, $1 \mathrm{a}$ and 5 were obtained in pure state for the first time. Regioselective preparation of 5-iodo derivative (6) was also successful. After examining some nucleophilic substitution reactions of 1-methoxyindoles reported in this paper, we have found the order of relative reactivity as $5<1 a<6<4 b<4 a$, which correlates with the electron withdrawing ability of the 3-substituent. Comparisons of these reactivities and antifungal activities are now in progress.

\section{EXPERIMENTAL}

Melting points were determined on a Yanagimoto micro melting point apparatus and are uncorrected. IR spectra were determined with a Shimadzu IR-420 spectrophotometer, and ${ }^{1}$ H-NMR spectra with either a JEOL JNM FX100S or JEOL GSX-500 spectrometer with tetramethylsilane as an internal standard. MS spectra were recorded on a JEOL SX-102A spectrometer. Column chromatography was performed on silica gel ( $\mathrm{SiO}_{2}, 100-200$ mesh, from Kanto Chemical Co. Inc.). Preparative thin-layer chromatography 
(p-TLC) was performed on Merck Kiesel-gel $\mathrm{GF}_{254}$ (Type 60)( $\left.\mathrm{SiO}_{2}\right)$.

1-Methoxyindole-3-carboxylic acid (5) from 1-Methoxyindole-3-carbaldehyde (4a) - A solution of $\mathrm{NaClO}_{2}(5.233 \mathrm{~g}, 57.86 \mathrm{mmol})$ and $\mathrm{NaH}_{2} \mathrm{PO}_{4} \cdot 2 \mathrm{H}_{2} \mathrm{O}(6.770 \mathrm{~g}, 43.40 \mathrm{mmol})$ in $\mathrm{H}_{2} \mathrm{O}(30.0$ $\mathrm{mL})$ was added to a solution of $4 \mathrm{a}(507 \mathrm{mg}, 2.89 \mathrm{mmol})$ in $t$ - $\mathrm{BuOH}(30.0 \mathrm{~mL})$ and 2-methyl-2-butene $(30.0 \mathrm{~mL})$ at $0^{\circ} \mathrm{C}$ and the mixture was stirred for $39 \mathrm{~h}$ at $\mathrm{rt}$. After addition of $\mathrm{H}_{2} \mathrm{O}$, the whole was extracted with $\mathrm{CHCl}_{3}-\mathrm{MeOH}(95: 5, \mathrm{v} / \mathrm{v})$. The extract was washed with brine, dried over $\mathrm{Na}_{2} \mathrm{SO}_{4}$, and evaporated under reduced pressure to leave a solid, which was column-chromatographed on $\mathrm{SiO}_{2}$ with $\mathrm{CHCl}_{3}$ to give 5 (523 mg, 95\%). 5: mp $173-174{ }^{\circ} \mathrm{C}$ (colorless prisms, recrystallized from AcOEthexane). IR (KBr): 2910 (br), 1664, 1512, 1450, 1325, 1265, 1220, 1085, 1010, 945, 740, 729, 716, $623 \mathrm{~cm}^{-1} .{ }^{1} \mathrm{H}-\mathrm{NMR}\left(\mathrm{CDCl}_{3}\right) \delta: 4.18(3 \mathrm{H}, \mathrm{s}), 7.31(1 \mathrm{H}, \mathrm{dt}, J=1.1,7.6 \mathrm{~Hz}), 7.34(1 \mathrm{H}, \mathrm{dt}, J=1.1,7.6$ $\mathrm{Hz}), 7.49(1 \mathrm{H}, \mathrm{dt}, J=7.6,1.1 \mathrm{~Hz}), 8.06(1 \mathrm{H}, \mathrm{s}), 8.24(1 \mathrm{H}, \mathrm{dt}, J=7.6,1.1 \mathrm{~Hz}) . \mathrm{MS} m / z: 191\left(\mathrm{M}^{+}\right)$. Anal. Calcd for $\mathrm{C}_{10} \mathrm{H}_{9} \mathrm{NO}: \mathrm{C}, 62.82 ; \mathrm{H}, 4.75 ; \mathrm{N}, 7.33$. Found: $\mathrm{C}, 62.69 ; \mathrm{H}, 4.75 ; \mathrm{N}, 7.21$.

Methyl 1-Methoxyindole-3-carboxylate (1a) from 5 - A solution of diazomethane in ether $(30.0 \mathrm{~mL})$ was added dropwise to a solution of $5(252 \mathrm{mg}, 1.32 \mathrm{mmol})$ in $\mathrm{MeOH}(8.0 \mathrm{~mL})$ and the mixture was stirred for $1 \mathrm{~h}$ at $\mathrm{rt}$. The solvent was evaporated under reduced pressure to leave an oil, which was column-chromatographed on $\mathrm{SiO}_{2}$ with $\mathrm{CHCl}_{3}-\mathrm{MeOH}(99: 1, \mathrm{v} / \mathrm{v})$ to give $1 \mathrm{a}(268 \mathrm{mg}, 99 \%)$. 1a: mp $45-46^{\circ} \mathrm{C}$ (colorless prisms, recrystallized from $\mathrm{CHCl}_{3}$ ). IR (film): 3125, 2990, 1700 (br), 1520, 1490, $1455,1440,1375,1330,1260,1210,1150,1120,1088,1027,961,775,750,730 \mathrm{~cm}^{-1}$. ${ }^{\mathrm{H}-\mathrm{NMR}}$ $\left(\mathrm{CDCl}_{3}\right)$ 8: $3.91(3 \mathrm{H}, \mathrm{s}), 4.15(3 \mathrm{H}, \mathrm{s}), 7.28(1 \mathrm{H}, \mathrm{dt}, J=1,7.8 \mathrm{~Hz}), 7.32(1 \mathrm{H}, \mathrm{dt}, J=1,7.8 \mathrm{~Hz}), 7.46$ $(1 \mathrm{H}, \mathrm{dt}, J=7.8,1 \mathrm{~Hz}), 7.96(1 \mathrm{H}, \mathrm{s}), 8.17(1 \mathrm{H}, \mathrm{dt}, J=7.8,1 \mathrm{~Hz})$. High-resolution MS $m / z$ : Calcd for $\mathrm{C}_{11} \mathrm{H}_{11} \mathrm{NO}_{3}$ : 205.0742. Found: 205.0739 .

Methyl 5-Iodo-1-methoxyindole-3-carboxylate (6) from 1a - KI (607 mg, $3.66 \mathrm{mmol})$ and $\mathrm{NaIO}_{4}(783 \mathrm{mg}, 3.65 \mathrm{mmol})$ were added to a solution of $1 \mathrm{a}(150 \mathrm{mg}, 0.73 \mathrm{mmol})$ in TFA $(4.0 \mathrm{~mL})$ and $\mathrm{H}_{2} \mathrm{O}(1.0 \mathrm{~mL})$ and the mixture was stirred for $24 \mathrm{~h}$ at $\mathrm{rt}$. After addition of ice and $\mathrm{H}_{2} \mathrm{O}$, the whole was extracted with $\mathrm{CHCl}_{3}-\mathrm{MeOH}(9: 1, \mathrm{v} / \mathrm{v})$. The extract was washed with brine, dried over $\mathrm{Na}_{2} \mathrm{SO}_{4}$, and evaporated under reduced pressure to leave an oil, which was column-chromatographed on $\mathrm{SiO}_{2}$ with $\mathrm{CHCl}_{3}$ to give 6 (166 mg, 69\%). 6: pale yellow gum. IR (KBr): 1708, 1523, 1453, 1361, 1205, 1084 $\mathrm{cm}^{-1} .{ }^{1} \mathrm{H}-\mathrm{NMR}\left(\mathrm{CDCl}_{3}\right)$ 8: $3.91(3 \mathrm{H}, \mathrm{s}), 4.13(3 \mathrm{H}, \mathrm{s}), 7.24(1 \mathrm{H}, \mathrm{dd}, J=8.8,0.7 \mathrm{~Hz}), 7.58(1 \mathrm{H}$, brd, $J=8.8 \mathrm{~Hz}), 7.90(1 \mathrm{H}, \mathrm{s}), 8.52\left(1 \mathrm{H}\right.$, brs). High-resolution MS $m / z$ : Calcd for $\mathrm{C}_{11} \mathrm{H}_{10} \mathrm{NO}_{3} \mathrm{I}: 330.9707$. Found: 330.9705 .

Methyl 5-Iodo- (7), 6-Iodo- (8), and 7-Iodoindole-3-carboxylate (9) from Methyl indole-3 -carboxylate $(1 \mathrm{~b})-\mathrm{KI}(1.700 \mathrm{~g}, 10.2 \mathrm{mmol})$ and $\mathrm{NaIO}_{4}(2.192 \mathrm{~g}, 10.2 \mathrm{mmol})$ were added to a solution of $1 \mathrm{~b}(300 \mathrm{mg}, 1.72 \mathrm{mmol})$ in TFA $(8 \mathrm{~mL})$ and $\mathrm{H}_{2} \mathrm{O}(3 \mathrm{~mL})$ and the mixture was stirred for $48 \mathrm{~h}$ at $20^{\circ} \mathrm{C}$. After addition of ice and $\mathrm{H}_{2} \mathrm{O}$, the whole was extracted with $\mathrm{CHCl}_{3}-\mathrm{MeOH}(9: 1, \mathrm{v} / \mathrm{v})$. The extract was washed successively with aq. $10 \%$ sodium thiosulfate and brine, dried over $\mathrm{Na}_{2} \mathrm{SO}_{4}$, and evaporated under reduced pressure to leave solid, which was repeatedly column-chromatographed on $\mathrm{SiO}_{2}$ with AcOEt-hexane (1:4-2:3, v/v) to give 9 (11 mg, 2\%), $8(131 \mathrm{mg}, 25 \%)$, and $7(300 \mathrm{mg}, 58 \%)$ in the order of elution. 7: $\mathrm{mp} 243.0-243.5^{\circ} \mathrm{C}$ (colorless prisms, recrystallized from $\mathrm{MeOH}$ ). IR $(\mathrm{KBr}$ ): $3200,1676,1525,1442,1192,1175 \mathrm{~cm}^{-1}$. 1 $\mathrm{H}-\mathrm{NMR}\left(\mathrm{CDCl}_{3}-\mathrm{CD}_{3} \mathrm{OD}, 1: 1\right) \delta: 3.89(3 \mathrm{H}, \mathrm{s}), 7.16(1 \mathrm{H}$, 
d, $J=8.5 \mathrm{~Hz}), 7.48(1 \mathrm{H}, \mathrm{dd}, J=8.5,2 \mathrm{~Hz}), 7.84(1 \mathrm{H}, \mathrm{s}), 8.44(1 \mathrm{H}, \mathrm{d}, J=2 \mathrm{~Hz}) . \mathrm{MS} \mathrm{m} / \mathrm{z}: 301\left(\mathrm{M}^{+}\right)$. Anal. Calcd for $\mathrm{C}_{10} \mathrm{H}_{8} \mathrm{NO}_{2} \mathrm{I}$ : C, 39.88; H, 2.67; N, 4.65. Found: C, 39.89; H, 2.59; N, 4.70. 8: mp $238.0-238.5^{\circ} \mathrm{C}$ (colorless prisms, recrystallized from $\mathrm{MeOH}$ ). IR (KBr): 3200, 1670, 1513, 1198, $1050,802 \mathrm{~cm}^{-1} .{ }^{1} \mathrm{H}-\mathrm{NMR}\left(\mathrm{CDCl}_{3}-\mathrm{CD}_{3} \mathrm{OD}, 9: 1\right) \delta: 3.91(3 \mathrm{H}, \mathrm{s}), 7.48$ (1H, dd, J=8, $\left.2 \mathrm{~Hz}\right), 7.76(1 \mathrm{H}$, dd, $J=2,0.5 \mathrm{~Hz}), 7.84(1 \mathrm{H}, \mathrm{s}), 7.88(1 \mathrm{H}, \mathrm{dd}, J=8,0.5 \mathrm{~Hz}) . \mathrm{MS} \mathrm{m} / z: 301\left(\mathrm{M}^{+}\right)$. Anal. Calcd for $\mathrm{C}_{10} \mathrm{H}_{8} \mathrm{NO}_{2} \mathrm{I}: \mathrm{C}, 39.88 ; \mathrm{H}, 2.67 ; \mathrm{N}, 4.65$. Found: $\mathrm{C}, 39.92 ; \mathrm{H}, 2.57 ; \mathrm{N}, 4.63 .9: \mathrm{mp} 154.5-155.0^{\circ} \mathrm{C}$ (colorless prisms, recrystallized from $\mathrm{MeOH}$ ). IR (KBr): 3210, 1675, 1444, 1300, 1190, 780, $720 \mathrm{~cm}^{-1}$.

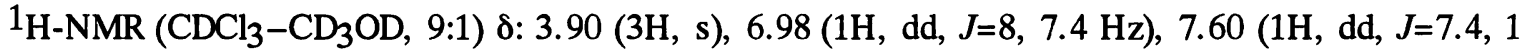
$\mathrm{Hz}$ ), 7.96 (total 1H, s and d, $J=3 \mathrm{~Hz}$ ), $8.11(1 \mathrm{H}$, dd, $J=8,1 \mathrm{~Hz})$. MS m/z: $301\left(\mathrm{M}^{+}\right)$. Anal. Calcd for $\mathrm{C}_{10} \mathrm{H}_{8} \mathrm{NO}_{2} \mathrm{I}: \mathrm{C}, 39.88 ; \mathrm{H}, 2.67 ; \mathrm{N}, 4.65$. Found: $\mathrm{C}, 39.69 ; \mathrm{H}, 2.51 ; \mathrm{N}, 4.70$.

Methyl 2-Methylthioindole-3-carboxylate (10) from $1 \mathrm{a}-$ Excess $15 \%$ aqueous sodium thiomethoxide $(9.0 \mathrm{~mL})$ was added to a solution of $1 \mathrm{a}(62 \mathrm{mg}, 0.30 \mathrm{mmol})$ in DMF $(3.0 \mathrm{~mL})$ and the mixture was stirred for $6 \mathrm{~h}$ at $60^{\circ} \mathrm{C}$. After addition of $\mathrm{H}_{2} \mathrm{O}$, the whole was made acidic by adding aqueous $1 \mathrm{~N} \mathrm{HCl}$ with ice-cooling and extracted with AcOEt. The extract was washed with brine, dried over $\mathrm{Na}_{2} \mathrm{SO}_{4}$, and evaporated under reduced pressure to leave an oil, which was column-chromatographed on $\mathrm{SiO}_{2}$ with $\mathrm{CHCl}_{3}-\mathrm{MeOH}(99: 1, \mathrm{v} / \mathrm{v})$ to give $10(47 \mathrm{mg}, 70 \%)$ and $5(17 \mathrm{mg}, 29 \%)$ in the order of elution. 10: $\mathrm{mp}$ $105-107^{\circ} \mathrm{C}$ (colorless fine needles, recrystallized from $\mathrm{CHCl}_{3}$-hexane). IR (KBr): 3300, 1660 (br), $1450,1200,1068,758 \mathrm{~cm}^{-1} .1_{\mathrm{H}-\mathrm{NMR}}\left(\mathrm{CDCl}_{3}\right) \delta: 2.63(3 \mathrm{H}, \mathrm{s}), 3.96(3 \mathrm{H}, \mathrm{s}), 7.18(1 \mathrm{H}, \mathrm{t}, J=7.8 \mathrm{~Hz})$, $7.22(1 \mathrm{H}, \mathrm{t}, J=7.8 \mathrm{~Hz}), 7.32(1 \mathrm{H}, \mathrm{d}, J=7.8 \mathrm{~Hz}), 8.03(1 \mathrm{H}, \mathrm{d}, J=7.8 \mathrm{~Hz}), 8.45(1 \mathrm{H}, \mathrm{br} \mathrm{s}) . \mathrm{MS} m / z: 221$ $\left(\mathrm{M}^{+}\right)$. Anal. Calcd for $\mathrm{C}_{11} \mathrm{H}_{11} \mathrm{NO}_{2} \mathrm{~S} \cdot 1 / 2 \mathrm{H}_{2} \mathrm{O}: \mathrm{C}, 57.39 ; \mathrm{H}, 5.21 ; \mathrm{N}, 6.08$. Found: C, 57.65; H, 5.02; N, 5.96.

Methyl 2-(Indol-1-yl)indole-3-carboxylate (14) from 1a - A solution of indole (19 $\mathrm{mg}, 0.16$ mmol) in anhydrous DMF $(2.0 \mathrm{~mL})$ was added to $60 \% \mathrm{NaH}(4.8 \mathrm{mg}, 0.12 \mathrm{mmol})$ with ice-cooling and the mixture was stirred for $15 \mathrm{~min}$ at $\mathrm{rt}$. To the resultant solution, a solution of $1 \mathrm{a}(17 \mathrm{mg}, 0.08 \mathrm{mmol})$ in anhydrous DMF $(1.0 \mathrm{~mL})$ was added and the mixture was stirred for $16 \mathrm{~h}$ at $\mathrm{rt}$. After addition of $\mathrm{H}_{2} \mathrm{O}$, the whole was extracted with AcOEt. The extract was washed with brine, dried over $\mathrm{Na}_{2} \mathrm{SO}_{4}$, and evaporated under reduced pressure to leave an oil, which was column-chromatographed on $\mathrm{SiO}_{2}$ with $\mathrm{CHCl}_{3}$-hexane $(1: 1, \mathrm{v} / \mathrm{v})$ to give $14(18 \mathrm{mg}, 77 \%) .14: \mathrm{mp} 159-160^{\circ} \mathrm{C}$ (colorless prisms, recrystallized from $\mathrm{CHCl}_{3}-$

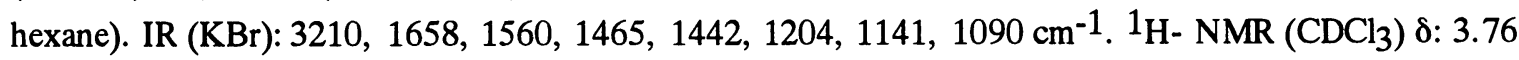
$(3 \mathrm{H}, \mathrm{s}), 6.72(1 \mathrm{H}, \mathrm{dd}, J=3.4,0.7 \mathrm{~Hz}), 7.20(1 \mathrm{H}, \mathrm{dt}, J=1.7,7.1 \mathrm{~Hz}), 7.24(1 \mathrm{H}, \mathrm{dt}, J=1.7,7.1 \mathrm{~Hz})$, $7.33-7.36(2 \mathrm{H}, \mathrm{m}), 7.37-7.40(2 \mathrm{H}, \mathrm{m}), 7.43(1 \mathrm{H}, \mathrm{d}, J=3.4 \mathrm{~Hz}), 7.68(1 \mathrm{H}, \mathrm{dd}, J=7.1,1.7 \mathrm{~Hz}), 8.24$ $-8.26(1 \mathrm{H}, \mathrm{m}), 8.71\left(1 \mathrm{H}\right.$, br s, disappeared on addition of $\left.\mathrm{D}_{2} \mathrm{O}\right)$. MS $m / z: 290\left(\mathrm{M}^{+}\right)$. Anal. Calcd for $\mathrm{C}_{18} \mathrm{H}_{14} \mathrm{~N}_{2} \mathrm{O}_{2} \cdot 1 / 3 \mathrm{H}_{2} \mathrm{O}: \mathrm{C}, 72.97 ; \mathrm{H}, 4.95 ; \mathrm{N}, 9.46$. Found: $\mathrm{C}, 72.74 ; \mathrm{H}, 4.84 ; \mathrm{N}, 9.41$.

Methyl 2-(Imidazol-1-yl)indole-3-carboxylate (16) from 1a - A solution of imidazole (80 $\mathrm{mg}, 1.17 \mathrm{mmol})$ in anhydrous DMF $(2.0 \mathrm{~mL})$ was added to $60 \% \mathrm{NaH}(21 \mathrm{mg}, 0.88 \mathrm{mmol})$ with icecooling and the mixture was stirred for $15 \mathrm{~min}$ at $\mathrm{rt}$. To the resultant solution, a solution of $1 \mathrm{a}(60 \mathrm{mg}$, $0.29 \mathrm{mmol})$ in anhydrous DMF $(3.0 \mathrm{~mL})$ was added and the mixture was stirred for $25 \mathrm{~h}$ at $60^{\circ} \mathrm{C}$. After addition of $\mathrm{H}_{2} \mathrm{O}$, the whole was extracted with AcOEt. The extract was washed with brine, dried over $\mathrm{Na}_{2} \mathrm{SO}_{4}$, and evaporated under reduced pressure to leave a solid, which was recrystallized from $\mathrm{MeOH}$ to 
give $16(15 \mathrm{mg})$. Mother liquor was subjected to $\mathrm{p}-\mathrm{TLC}$ on $\mathrm{SiO}_{2}$ with $\mathrm{CHCl}_{3}-\mathrm{MeOH}(95: 5$, v/v) as a developing solvent. Under UV light, theree bands were detected. Extraction of the band ( $R f$ value: $0.96-0$. 80) with $\mathrm{CHCl}_{3}-\mathrm{MeOH}(9: 1, \mathrm{v} / \mathrm{v})$ afforded unreacted $1 \mathrm{a}(21 \mathrm{mg}, 36 \%)$. Extraction with the same solvent as above, $5.6 \mathrm{mg}(11 \%)$ of $1 \mathrm{~b}$ was obtained from the band ( $R f$ value: $0.68-0.50)$. Similarly, further crop of $16(5 \mathrm{mg})$ was obtained from the band ( $R f$ value: $0.29-0.18)$. Total yield of 16 was $20 \mathrm{mg}$ (28\%). 16: $\mathrm{mp} 265-266^{\circ} \mathrm{C}$ (colorless needles, recrystallized from $\mathrm{MeOH}$ ). IR (KBr): 1691, 1460, 1345, 1215, 1060, 745, $720 \mathrm{~cm}^{-1}$. 1 ${ }_{\mathrm{H}-\mathrm{NMR}}$ (DMSO-d 6$)$ 8: $3.75(3 \mathrm{H}, \mathrm{s}), 7.11(1 \mathrm{H}, \mathrm{s}), 7.24(1 \mathrm{H}, \mathrm{dt}, J=1.2$, $7.3 \mathrm{~Hz}), 7.27(1 \mathrm{H}, \mathrm{dt}, J=1.2,7.3 \mathrm{~Hz}), 7.44(1 \mathrm{H}, \mathrm{dt}, J=1.2,7.3 \mathrm{~Hz}), 7.60(1 \mathrm{H}, \mathrm{t}, J=1.2 \mathrm{~Hz}), 8.04(1 \mathrm{H}$, dd, $J=7.3,1.2 \mathrm{~Hz}), 8.11(1 \mathrm{H}, \mathrm{s})$. MS $m / z: 241\left(\mathrm{M}^{+}\right)$. Anal. Calcd for $\mathrm{C}_{13} \mathrm{H}_{11} \mathrm{~N}_{3} \mathrm{O}_{2}$ : C, 64.72; $\mathrm{H}, 4.60$; $\mathrm{N}, 17.42$. Found: $\mathrm{C}, 64.59 ; \mathrm{H}, 4.60 ; \mathrm{N}, 17.29$.

Methyl 2-(Imidazol-1-yl)-5-iodoindole-3-carboxylate(19) from 6 - A solution of imidazole $(34 \mathrm{mg}, 0.51 \mathrm{mmol})$ in anhydrous DMF $(1.0 \mathrm{~mL})$ was added to $60 \% \mathrm{NaH}(15 \mathrm{mg}, 0.38 \mathrm{mmol})$ with ice-cooling and the mixture was stirred for $10 \mathrm{~min}$ at $\mathrm{rt}$. To the resultant solution, a solution of 6 (42 $\mathrm{mg}$, $0.12 \mathrm{mmol})$ in anhydrous DMF $(2.0 \mathrm{~mL})$ was added and the mixture was stirred for $23 \mathrm{~h}$ at $62^{\circ} \mathrm{C}$. After addition of $\mathrm{H}_{2} \mathrm{O}$, the whole was extracted with AcOEt. The extract was washed with brine, dried over $\mathrm{Na}_{2} \mathrm{SO}_{4}$, and evaporated under reduced pressure to leave a solid, which was column-chromatographed on $\mathrm{SiO}_{2}$ with $\mathrm{AcOEt}$-hexane (2:1, v/v) to give 19 (36 mg, 72\%). 19: $\mathrm{mp} 271-272{ }^{\circ} \mathrm{C}$ (colorless prisms, recrystallized from $\mathrm{MeOH}$ ). IR (KBr): 1692, 1490, 1441, 1218, 1161, $1062 \mathrm{~cm}^{-1} .1_{\text {H-NMR (DMSO-d }}$ ) $\delta: 3.76(3 \mathrm{H}, \mathrm{s}), 7.11(1 \mathrm{H}, \mathrm{s}), 7.30(1 \mathrm{H}, \mathrm{d}, J=8.5 \mathrm{~Hz}), 7.54(1 \mathrm{H}, \mathrm{dd}, J=8.5,1.7 \mathrm{~Hz}), 7.61(1 \mathrm{H}, \mathrm{br} \mathrm{s})$, $8.12(1 \mathrm{H}, \mathrm{s}), 8.29\left(1 \mathrm{H}, \mathrm{s}\right.$, disappeared on addition of $\left.\mathrm{D}_{2} \mathrm{O}\right), 8.35(1 \mathrm{H}, \mathrm{d}, J=1.7 \mathrm{~Hz}) . \mathrm{MS} \mathrm{m} / z: 367$ $\left(\mathrm{M}^{+}\right)$. Anal. Calcd for $\mathrm{C}_{13} \mathrm{H}_{10} \mathrm{~N}_{3} \mathrm{O}_{2} \mathrm{I}$ : C, 42.52; H, 2.73; N, 11.44. Found: C, 42.38; H, 2.76; $\mathrm{N}, 11.16$.

Methyl 2-(Indol-1-yl)-5-iodoindole-3-carboxylate (20) from 6 - A solution of indole (18 $\mathrm{mg}, 0.15 \mathrm{mmol})$ in anhydrous DMF $(2.0 \mathrm{~mL})$ was added to $60 \% \mathrm{NaH}(4.7 \mathrm{mg}, 0.12 \mathrm{mmol})$ with icecooling and the mixture was stirred for $15 \mathrm{~min}$ at $\mathrm{rt}$. To the resultant solution, a solution of $6(26 \mathrm{mg}, 0.08$ $\mathrm{mmol})$ in anhydrous DMF $(1.5 \mathrm{~mL})$ was added and the mixture was stirred for $17.5 \mathrm{~h}$ at $\mathrm{rt}$. After addition of $\mathrm{H}_{2} \mathrm{O}$, the whole was extracted with AcOEt. The extract was washed with brine, dried over $\mathrm{Na}_{2} \mathrm{SO}_{4}$, and evaporated under reduced pressure to leave an oil, which was column-chromatographed on $\mathrm{SiO}_{2}$ with $\mathrm{CHCl}_{3}$-hexane $(2: 1, \mathrm{v} / \mathrm{v})$ to give $20(25 \mathrm{mg}, 77 \%) .20: \mathrm{mp} 192-194^{\circ} \mathrm{C}$ (colorless prisms, recrystallized from $\mathrm{CHCl}_{3}$-hexane). IR (KBr): $1668,1558,1273,1204,1144 \mathrm{~cm}^{-1} .{ }^{1} \mathrm{H}-\mathrm{NMR}\left(\mathrm{CDCl}_{3}\right) \delta: 3.78(3 \mathrm{H}$, s), $6.72(1 \mathrm{H}, \mathrm{d}, J=3.4 \mathrm{~Hz}), 7.16(1 \mathrm{H}, \mathrm{d}, J=8.6 \mathrm{~Hz}), 7.22(1 \mathrm{H}, \mathrm{dt}, J=1.7,7.1 \mathrm{~Hz}), 7.25(1 \mathrm{H}, \mathrm{dt}, J=1.7$, $8.1 \mathrm{~Hz}), 7.37(1 \mathrm{H}, \mathrm{d}, J=8.1 \mathrm{~Hz}), 7.43(1 \mathrm{H}, \mathrm{d}, J=3.4 \mathrm{~Hz}), 7.60(1 \mathrm{H}, \mathrm{dd}, J=8.6,1.7 \mathrm{~Hz}), 7.68(1 \mathrm{H}$, dd, $J=8.1,1.7 \mathrm{~Hz}), 8.59(1 \mathrm{H}, \mathrm{d}, J=1.7 \mathrm{~Hz}), 8.83\left(1 \mathrm{H}, \mathrm{s}\right.$, disappeared on addition of $\left.\mathrm{D}_{2} \mathrm{O}\right)$. MS $m / z: 416$ $\left(\mathrm{M}^{+}\right)$. Anal. Calcd for $\mathrm{C}_{18} \mathrm{H}_{13} \mathrm{~N}_{2} \mathrm{O}_{2} \mathrm{I} \cdot 1 / 2 \mathrm{H}_{2} \mathrm{O}: \mathrm{C}, 50.84 ; \mathrm{H}, 3.29 ; \mathrm{N}, 6.59$. Found: C, 50.80; H, 3.04; $\mathrm{N}, 6.46$.

Dimethyl 2-(5-Iodo-3-methoxycarbonylindol-2-yl)malonate (24) from 6 - A solution of dimethyl malonate $(96 \mathrm{mg}, 0.72 \mathrm{mmol})$ in anhydrous DMF $(8.0 \mathrm{~mL})$ was added to $\mathrm{KO}$ - $\mathrm{Bu}(81 \mathrm{mg}, 0.72$ $\mathrm{mmol})$ and the mixture was stirred for $10 \mathrm{~min}$ at rt. To the resultant solution, a solution of $6(60 \mathrm{mg}, 0.18$ $\mathrm{mmol})$ in anhydrous DMF $(4.0 \mathrm{~mL})$ was added and the mixture was stirred for $9 \mathrm{~h}$ at $72^{\circ} \mathrm{C}$. After addition 
of $\mathrm{H}_{2} \mathrm{O}$ and ice, the whole was extracted with $\mathrm{AcOEt}-\mathrm{MeOH}(95: 5, \mathrm{v} / \mathrm{v})$. The extract was washed with brine, dried over $\mathrm{Na}_{2} \mathrm{SO}_{4}$, and evaporated under reduced pressure to leave an oil, which was subjected to p-TLC on $\mathrm{SiO}_{2}$ with $\mathrm{CHCl}_{3}$-hexane $(4: 1, \mathrm{v} / \mathrm{v}$ ) as a developing solvent. Extraction of the band ( $R f$ value: $0.87-0.65)$ with $\mathrm{CHCl}_{3}$ gave unreacted 6 ( $24 \mathrm{mg}, 40 \%$ ). Extraction of the band ( $R f$ value: $0.45-0.23$ ) with $\mathrm{CHCl}_{3}$ gave 24 (20 mg, 25\%). 24: $\mathrm{mp} 159-160^{\circ} \mathrm{C}$ (colorless prisms, recrystallized from $\mathrm{CHCl}_{3}-\mathrm{h}$ exane). IR (KBr): 1729 (br), 1691, 1436, 1260, 1085, $1023 \mathrm{~cm}^{-1} .1_{\mathrm{H}-\mathrm{NMR}}\left(\mathrm{CDCl}_{3}\right)$ 8: 3.81 (6H, s), $3.96(3 \mathrm{H}, \mathrm{s}), 6.23(1 \mathrm{H}, \mathrm{s}), 7.20(1 \mathrm{H}, \mathrm{d}, J=8.6 \mathrm{~Hz}), 7.54(1 \mathrm{H}, \mathrm{dd}, J=8.6,1.7 \mathrm{~Hz}), 8.46(1 \mathrm{H}, \mathrm{d}, J=1.7$ $\mathrm{Hz}), 9.70\left(1 \mathrm{H}\right.$, brs). High-resolution MS $m / z$ : Calcd for $\mathrm{C}_{15} \mathrm{H}_{14} \mathrm{NO}_{6} \mathrm{I}: 430.9860$. Found: 430.9866.

\section{REFERENCES AND NOTES}

1. a) Dedicated to the 77th birthday of Prof. Shô Itô. b) This is Part 98 of a series entitled "The Chemistry of Indoles”. Part 97: F. Yamada, A. Goto, and M. Somei, Heterocycles, 2000, 53, 1255.

2. M. Soledade, C. Pedras, and J. L. Sorensen, Phytochemistry, 1998, 49, 1959. These authors did not cite us in spite of using our 1-methoxyindole synthetic method. 4 Other recent unfair example is the following: D. L. Boger, H. Keim, B. Oberhauser, E. P. Schreiner, and C. A. Foster, J. Am. Chem. Soc., 1999, 121, 6197.

3. R. M. Acheson, P. G. Hunt, D. M. Littlewood, B. A. Murrer, and H. E. Rosenberg, J. Chem. Soc., Perkin Trans. 1, 1978, 1117.

4. M. Somei and T. Kawasaki, Heterocycles, 1989, 29, 1251; M. Somei, T. Kawasaki, K. Shimizu, Y. Fukui, and T. Ohta, Chem. Pharm. Bull., 1991, 39, 1905; Review: M. Somei, Heterocycles, 1999, 50, 1157 and references cited therein.

5. F. Yamada, D. Shinmyo, and M. Somei, Heterocycles, 1994, 38, 273 and see the reference 2 in the paper.

6. M. Somei, M. Nakajou, T. Teramoto, A. Tanimoto, and F. Yamada, Heterocycles, 1999, 51, 1949.

7. M. Somei, H. Morikawa, K. Yamada, and F. Yamada, Heterocycles, 1998, 48, 1117; J. A Joule, "Progress in Heterocyclic Chemistry", Vol. 11, ed. by G. W. Gribble and T. L. Gilchrist, Elsevier Science Ltd., Oxford, 1999, pp. 45-65; M. Hasegawa, K. Yamada, Y. Nagahama, and M. Somei, Heterocycles, 1999, 51, 2815. See also references, 4 and 5.

8. a) M. Takasugi, K. Monde, N. Katsui, and A. Shirata, Bull. Chem. Soc. Japan, 1988, 61, 285; M. Takasugi, Kagaku to Seibutu, 1993, 31, 22 and references cited therein. b) Synthesis of 12: M. Somei, T. Kawasaki, Y. Fukui, F. Yamada, T. Kobayashi, H. Aoyama, and D. Shinmyo, Heterocycles, 1992, 61, 1877.

9. B. S. Bal, W. E. Childers, Jr., and H. W. Pinnick, Tetrahedron, 1981, 37, 2091.

10. H. O. Wirth, O. Konigstein, and W. Kern, Liebigs Ann. Chem., 1960, 634, 84; D. L. Mattern and X. Chen, J. Org. Chem., 1991, 56, 5903.

11. M. Somei, F. Yamada, and G. Yamamura, Chem. Pharm. Bull., 1998, 46, 191. 